\title{
La saga de los Marx de Goytisolo: Marx Kultur y Mass Culture en la pantalla televisiva
}

\author{
La saga de los Marx by Goytisolo: Marx Kultur \\ and Mass Culture on the television screen
}

\author{
Simone Cattaneo \\ Università degli Studi de Milán, Dipartimento di Lingue e Letterature Straniere, \\ Milán, Italia. Correo electrónico: simone.cattaneo@unimi.it
}

En el presente artículo nos proponemos analizar cómo se imbrican en La saga de los Marx (1993), del escritor Juan Goytisolo (Barcelona, 1931), los lenguajes propios del medio televisivo y la prosa performativa y metanarrativa del autor barcelonés, sorteando las insidias de dicha hibridación, y combinándola con una cáustica crítica a la figura de Karl Marx y con las dictaduras derivadas de una lectura distorsionada de sus teorías. Goytisolo consigue no sólo reivindicar la necesidad de no rendirse a una conciencia ahistórica fomentada por el tan manido concepto de "final de la Historia", sino que, en una vuelta de tuerca de raigambre cervantina -llevada paradójicamente a cabo aprovechando elementos típicos de géneros audiovisuales como el documental, el docudrama, las series de televisión y el talk show-, logra revitalizar lo literario en el ámbito de una sociedad posmoderna dominada por la tecnología.

Palabras clave: Juan Goytisolo, La saga de los Marx, televisión, medios de comunicación de masas, posmodernidad

This paper aims to analyze how Juan Goytisolo (Barcelona, 1931) combines together the narrative practices of television and his performative and metanarrative writing in La saga de los Marx (1993). The author uses that hybrid prose for two principal purposes: on one hand he criticizes the figure of Karl Marx and the dictatorial application of his theories by some governments, claiming for the need to avoid the widespread ahistorical vision created by the too often announced "end of History"; and, on the other hand, emphasizing the ironic approach inherited from Cervantes, he paradoxically uses some audiovisual genres -such as documentaries, docudramas, TV series and talk shows- to revitalize literature in a postmodern society that relies too much on technologies.

Key words: Juan Goytisolo, La saga de los Marx, television, mass media, postmodernity 
"El espectáculo es el capital a un grado de acumulación tal que éste deviene imagen"

(Debord 1995: 19)

La saga de los Marx (1993) ocupa un lugar peculiar en la narrativa de Juan Goytisolo (Barcelona, 1931), y se sitúa en uno de esos recodos de sombra que marcan un punto de inflexión o un cambio de rumbo en la trayectoria literaria de un autor. La crítica, de hecho, suele indicar dicho texto como el que inauguraría la que se ha dado en llamar "obra tardía" de Goytisolo (Adriaensen 2007; Adriaensen y Kunz 2009), o como un volumen que representaría una exacerbación de ciertas características que ya en Paisajes después de la batalla (1982) anunciaban en el seno de la escritura goytisoliana una nueva tendencia (Cornago 2005: 59). Quizás, precisamente por su posición liminar, este libro ha engendrado opiniones contrapuestas (Ribeiro de Menezes 2005: 130), y ha sido objeto de un número exiguo de estudios (Davis 2009: 36) que, en su mayoría, se han centrado en la revisitación de unos pliegues históricos y políticos imprescindibles para entender los siglos XIX y XX, o en los juegos metaficcionales aprovechados para tal fin ${ }^{1}$.

Sin embargo, desde una perspectiva conceptual y textual que nos permitiría adentrarnos ulteriormente en los entresijos del escrito, cabría destacar otro elemento cuya presencia ha sido resaltada a menudo pero sin la necesaria hondura, como si la superficialidad intrínseca que con frecuencia se le atribuye en los círculos cultos determinara por parte de Goytisolo una actitud meramente referencial a la hora de insertarlo en la narración: el televisor ${ }^{2}$. La saga de los Marx no es sólo un agudo e irónico corolario a la caída del muro de Berlín, al desmoronamiento de los regímenes comunistas, y a la crisis de los ideales socialistas, sino que es, también, como apuntan Guillamón (1993: 48-49), Adriaensen (2007: 28) y Ferré (2011b: 280), una lectura amarga y lúcida del impacto de los medios de comunicación en la sociedad posmoderna, urdida imbricando el estilo experimental del autor con los procedimientos propios de las tecnologías audiovisuales.

La televisión, como recuerdan Abruzzese y Miconi (2002: 29), a partir de la década de los 50 se convirtió, en el ámbito occidental, en un experimento y un indicador del viraje de un sistema industrial -en el cual todavía podían tener vigencia las teorías marxistas- a otro post-industrial, y su lenguaje se configuró como el "más típico de la segunda mitad del siglo XX, de sus modelos de organización, de sus valores de

Ejemplos de estas aproximaciones críticas son el libro de Marco Kunz, La saga de los Marx de Goytisolo. Notas al texto (1997), y su ensayo "Contra los discursos totalitarios: En torno a la intertextualidad marxista y fascista en La saga de los Marx y Las semanas del jardín" (2009a), el capítulo "La saga de los Marx: Plaidoyer en faveur de la 'vérité' de la fiction littéraire" del volumen Juan Goytisolo. Le soi, le monde et la création littéraire (2009a) de Yannick Llored, el estudio "Re-escribiendo la historia como simulacro: La utopía del texto y La saga de los Marx" de Juan Francisco Ferré (2011a), y las comunicaciones "A vueltas con la historia: La saga de los Marx de Juan Goytisolo" de Margarita Almela (1996) y "¿La inviabilidad de la novela histórica? La saga de los Marx, de Juan Goytisolo" de José Antonio Pérez Bowie, ambas incluidas en La novela histórica a finales del siglo XX. Actas del V Seminario Internacional del Instituto de Semiótica Literaria y Teatral de la UNED (1996).

2 Es curioso notar que desde 1989, año de la caída del muro de Berlín, hasta 1997 se registró en España una abrumadora expansión del medio televisivo (Rueda Laffond y Chicharro Merayo 2006: 355). Así también, nos parece significativo poner de relieve que la programación diaria española de los 80 y comienzos de los 90 estaba dominada por las teleseries norteamericanas (2006: 355), una situación que, a todas luces, reproducía a escala local un modelo global en el cual muy probablemente se inspiró Goytisolo, dado que en La saga de los Marx cita a menudo la serie Dallas, una producción estadounidense muy conocida y que encandiló a los televidentes de todo el mundo con su aparatoso american way of life a lo largo de casi tres lustros, desde 1978 hasta 1991. 
uso y de sus valores de intercambio económico y simbólico" (2002: 31). Se trataría, entonces, de un instrumento que ha logrado ser espejo y alimento de un capitalismo proyectado a superar sus contradicciones, extendiendo su afán consumista a los países del ex bloque soviético, y vendiendo a los habitantes del tercer mundo el espejismo de un paraíso uniformador, algo que Goytisolo representa a través de la llegada de los albaneses a las costas italianas en 1991:

algunos no habían podido resistir la imantación de la nueva Judea y se zambullían desde los botes para alcanzar más pronto la orilla, nadaban de modo estrepitoso y enérgico, con sus cabezas flotadoras cada vez más próximas, alentados por unos sentimientos de calor y amistad hacia los paladines del bienestar y la libre empresa, iguales, igualitos, a los que habían contemplado hipnotizados en la publicidad televisiva o en los seriales ambientados en Texas, el paraíso, el paraíso al fin, ¡tangible y concreto! (Goytisolo 2005: 17).

Además, en cuanto dispositivo individual de masificación (Abruzzese y Miconi 2002: 28), la pantalla televisiva ha ido socavando el principio de lucha enunciado por Karl Marx, al quebrantar la unión de las masas en favor de una atomización masificada (Debord 1995: 17-18; Abruzzese y Miconi 2002: 49) apta para que el individuo preste su oído a la oferta hipertrofiada de una economía de libre mercado. Como señala Ferré (2011b: 301), parece haber sido ella una de las principales causas del derrumbe de los gobiernos comunistas, con su poder de seducción del imaginario colectivo por medio de unas imágenes que reemplazan creencias, ideologías y utopías ${ }^{3}$. He aquí que las ondas hertzianas podrían considerarse parte de ese "virus informático" (Goytisolo 2005: 32) que, en opinión de Jenny von Westphalen, debía de haber atacado el sistema marxista para acabar con él de esa forma abrupta y grotesca.

La creciente importancia de la dimensión escópica en la cotidianidad del ser humano a comienzos de los $90^{4}$ confirmaba los temores expresados por Debord en su escrutinio de la sociedad del espectáculo, y ponía los cimientos de la que Lipovetsky y Serroy (2009: 10) llaman la "era de la pantalla global", una contemporaneidad que implica el paso de la "pantalla espectáculo a la pantalla comunicación, de la unipantalla a la omnipantalla" (2009: 10). Esta deriva hacia una realidad en la que "el discurso de la imagen prevalece e imprime su carácter a la moda, a las relaciones sociales y al lenguaje de manera más directa que la vieja cultura escrita" (Navajas 2002: 25) es un aspecto que preocupa a Juan Goytisolo y, de hecho, lo visual, desde Paisajes después de la batalla, ha tenido cada vez más cabida en su escritura (Ribeiro de Menezes 2005: 119), hasta permear La saga de los Marx a un grado tal que

A este propósito es muy interesante una observación del escritor David Foster Wallace sobre los efectos de la televisión en la sociedad estadounidense, un razonamiento que es posible extender a las demás realidades nacionales: "American seemed no longer united so much by common beliefs as by common images: what binds us became what we stand witness to" (1998: 42). Abruzzese y Miconi refuerzan esta hipótesis: "La televisión ha comunicado, pues, más allá de toda barrera, ha creado colectivos más allá de su propia medida y, por tanto, ha dinamitado los acontecimientos de la historia. Al re-tomarlos y difundirlos ha hecho funcionar su puesta en escena como antes se creyó que podían funcionar las filosofías de la historia" (2002: 41).

$4 \quad$ En esa época en España se asistió a la eclosión de la televisión privada y la multiplicación de canales al alcance del público ibérico (Reig 2009: 80-83) de manera consecuente con lo que sucedía, o había sucedido, en otras partes del mundo y, luego, sobrevino la expansión masiva de los ordenadores y de Internet, que ha favorecido el desarrollo de otros dispositivos dotados de pantalla: "In 2010 the global internet-connected population will cross two billion people, and mobile phone accounts already number over three billion” (Shirky 2011: 23). 
Guillamón (1993: 49) llega a afirmar que frente a éste lo literario pasa en segundo término. Probablemente se trata de una aserción con cierto matiz provocador, aunque el mismo Goytisolo, en los andamiajes que, gracias a sus piruetas metaficcionales, quedan al descubierto en la novela, revela las conexiones que voluntariamente trabó entre los medios audiovisuales -considerados los heraldos de una homogeneización forzada $^{5}$, según una perspectiva influida sin duda por Baudrillard (2008: 71) y su escritura-, en un intento por "convertir el funcionamiento televisivo en fuente de creatividad y diálogo crítico" (Cornago 2005: 281):

en una sociedad uniformada por el imperio de la imagen, ¿qué valor literario y moral tendría poner la pluma al servicio de ésta y trazar relatos históricos como esas escenas reconstruidas en estudio de acontecimientos y crímenes sórdidos? ¿no sería más incitativo y fecundo desenmascarar los mitos e instancias intermedias que operan entre el gran público y Marx, integrando en la obra los filtros a través de los que percibimos su elusiva y contradictoria personalidad? en vez de resignarse a aceptar la escritura como sierva de la tecnología, ¿por qué no introducir los estereotipos y mediatizaciones de aquella en el ámbito de la novela, invirtiendo los papeles y subordinando las cotidianas irrupciones televisivas y sus mensajes subliminales a las reglas del campo de maniobra abierto por Cervantes? (Goytisolo 2005: 176-177).

Para que semejante estrategia fuera eficaz hacía falta tejer una red de miradas caleidoscópicas que establecieran las reglas de ese laberinto de espejos -o pantallastrazado por el autor y, entonces, si por un lado uno de sus objetivos principales era el de mostrar al lector la figura de Karl Marx seccionada por la cuchilla de sus admiradores o sus detractores a lo largo de la Historia, por otro lado esos juicios más o menos pormenorizados sobre él y su doctrina filosófico-política debían leerse a la luz de las hogueras, factuales o metafóricas, que habían alumbrado el fin de una época de ideales revolucionarios fagocitados y pervertidos por unas dictaduras atroces y escuálidas (Pérez Bowie 1996: 342), unas fogatas que habían sido retransmitidas puntualmente por las cámaras televisivas y con cuyas imágenes cualquier espectador estaba familiarizado ${ }^{6}$.

La fusión de estas dos perspectivas, aparentemente anacrónicas, sería posible a través de la mediación de la televisión porque, como recuerda Kunz (1997: 181) al citar una entrevista de Rosa Mora a Goytisolo, nuestra recepción de la estampa física e intelectual del coautor de El manifiesto del partido comunista depende, además

\footnotetext{
"un mundo gobernado por los intereses de una superpotencia y convertido a las virtudes de un dogma único que, no obstante el hecho de excluir de sus supuestos beneficios a clases enteras, a países enteros e incluso continentes enteros, se nos presenta como una panacea universal a través de la dictadura ubicua de una televisión destinada a privar a los seres humanos de su natural condición de sujetos pensantes para convertirlos en meros consumidores insaciables a quienes hay que vender sueños baratos, sexo o violencia por procuración, productos en serie y lujos inalcanzables" (Camacho 1993: 57).

$6 \quad$ Almela (1996: 128-129) incluso trata de establecer una conexión entre el comienzo de La saga de los Marx y la vida real de Juan Goytisolo, hipotizando que el 8 de agosto de 1991 éste hubiera podido ver en un televisor tanto la llegada de los albaneses al puerto de Bari como la película de Fellini E la nave va. Otro ejemplo de una "transcripción" fiel de los testimonios visuales de la época lo encontramos en las páginas 34 y 35 de la novela (Goytisolo 2005), en las que Jenny y Lenchen observan boquiabiertas el mercadillo improvisado alrededor de los restos del muro de Berlín en el que se cotizan los pedruscos de esa barrera que separaba el bloque occidental del oriental, y donde se malvenden los vestigios de la República Democrática Alemana; fotogramas repetidos hasta la saciedad por los televisores del mundo entero y, a estas alturas, tatuados en las retinas de los adultos y de quienes en aquellos años ya tenían uso de razón.
} 
de sus obras y los estudios críticos sobre las mismas, de las lecturas espectaculares que de ella se han realizado a través de la grande y pequeña pantalla. Parece, pues, perfectamente normal y corriente posicionar a Marx en el centro del ojo de una cámara $\mathrm{y}$, en un ulterior alarde de ingenio, convertirlo en televidente de cuanto está pasando en las naciones cuyos líderes políticos aplicaron a su antojo las bases teóricas elaboradas por él. De este modo, se teje una tupida telaraña de miradas sesgadas que funcionan como unas cajas chinas porque no sólo tendremos a un autor-narrador que ha contemplado, o está contemplando, en directo el derrumbe de los regímenes socialistas, sino que éste brinda a sus lectores-espectadores ${ }^{7}$ - quienes comparten con él las imágenes mediatizadas de la caída del bloque soviético- una familia Marx que, a su vez, está presenciando en el televisor de su casa los efectos devastadores de la debacle de las tesis defendidas por el pensador de Tréveris.

He aquí, pues, que todos se han convertido en televidentes, aunque el filósofo alemán y el narrador tendrán el privilegio -o la mala suerte- de ocupar de forma explícita también un espacio al otro lado de la pantalla: el primero durante un mitin (Goytisolo 2005: 41-46) y en el serial La Baronne Rouge (Goytisolo 2005: 125-151), mientras que el segundo se verá rodeado, a su pesar, de aguerridos contertulios en un delirante talk show (Goytisolo 2005: 155-181). Es éste, en efecto, el punto de vista que caracteriza la primera parte de La saga de los Marx, puesto que desde el arranque del texto -“¡Guarda Carlo! (¿lo había dicho en italiano?) ¡che bel transatlantico!” (p. 13) con su montaje en paralelo de las imágenes de un buque cargado de albaneses próximo a las costas adriáticas de Italia y las del lujoso barco de la película felliniana $E$ la nave $v a^{9}$, la estética que subyace a la escritura, y por consiguiente a la lectura, es la del zapeo (Ferré 2011b: 294), pasatiempo moderno retomado en la novela por Tussy:

¡Vaya confusión! ¡Secuencias entreveradas de un filme de Fellini y el reportaje en directo, desde el puerto de Bari, de un ferry atestado de fugitivos albaneses! el zapeo convulsivo de Tussy, su inveterada manía de teclear el programador a distancia, mezclaba imágenes, barajaba planos, pasaba del sofisticado transátlantico reconstruido en los estudios de Cinecittà al herrumbroso y maltrecho transbordador de jubilosa y exultante carga humana (Goytisolo 2005: 20).

El sucederse de retazos enhebrados caprichosamente y la polifonía son unos aspectos consustanciales a la escritura de Juan Goytisolo (Pérez Bowie 1996: 339; González Ortega 1999: 93; Cornago 2002: 118 y 2005: 50; Adriaensen 2009: 30; Llored 2009b: 42), y podrían considerarse unos recursos estéticos propicios para

Quizás aquí podríamos incluso emplear el concepto de "lectoespectador", expresado por Vicente Luis Mora en los siguientes términos: "el lectoespectador sería aquel receptor de una forma artística compuesta por texto más imagen" (2012: 19). Si bien en La saga de los Marx la única imagen es la fotografía de Lenchen en la página 193, las constantes referencias a unos fenómenos televisados y muy conocidos estimulan al lector para que los rescate de su mente y los superponga a la escritura del autor, en una relación de simbiosis entre los dos lenguajes.

8 Es sin duda llamativo el hecho de que Goytisolo elija empezar La saga de los Marx con el imperativo del verbo italiano "guardare" ("mirar"), resaltando así la importancia del elemento visual en la narración.

9 Según Almela, el largometraje, además de un irónico contrapunto al paquebote abarrotado de tránsfugas, encerraría en sí una anticipación de la estructura metaficcional del relato goytisoliano: "También en esta película el juego y mezcla de los tiempos cronológicos es rico y significativo, y también Fellini descubre explícitamente el juego entre ficción y realidad en uno de los últimos planos del film, cuando una de las cámaras desvía su objetivo hacia el director y las cámaras que filman las últimas secuencias" (1996: 129). 
establecer una primera conexión entre su estilo y el lenguaje televisivo. A ellos quizás cabría añadir una marcada autoconsciencia irónica, propia tanto de los postreros artefactos narrativos del autor (Cornago 2002: 124 y 2005: 60-61; Adriaensen 2007: 243 y 2009: 32) como de la pequeña pantalla y de la episteme posmoderna (Wallace 1998: 35), a pesar de que en cada caso se recurra a ella con diferentes grados de profundidad y agudeza.

La televisión es el paradigma de la actual crisis de la narratividad (González Requena 1999: 114), y su discurso se presenta como un caleidoscopio de "fragmentos, visiones y sobras" (Abruzzese y Miconi 2002: 241), un collage (Gordillo 1999: 15), una mezcla caótica (Machado 2009: 123), un flujo continuo (Imbert 2003: 25), abierto e interminable (González Requena 1999: 41), que absorbe las estrategias textuales de los géneros que incorpora en su interior (1999: 46), con constantes cambios de perspectivas (1999: 49) y una multiplicidad de voces que acaban por crear un efecto polifónico (1999: 33). Su condición de diversión doméstica y su flexibilidad narrativa ${ }^{10}$ difuminan, además, la raya que separa lo espectacular de lo real, ya que lo primero penetra en el entorno cotidiano del televidente (González Requena 1999: 102; Lipovetsky y Serroy 2009: 218), o los dos elementos se funden en la pantalla al alternarse -como en las secuencias iniciales de La saga de los Marx-grabaciones en directo de acontecimientos históricos con fotogramas de obras de ficción (Gordillo 1999: 12). De esta manera, el medio televisivo supone "una redefinición total de los propios atributos de verdad" (Abruzzese y Miconi 2002: 230), y crea una verdad y una realidad propias (Cornago 2005: 273), desvinculándose tanto de lo estrictamente referencial como de lo estrictamente ficcional (Imbert 2002: 27). Se trataría, entonces, de una tierra de nadie en la que todo es posible, un coto de caza que llega a coincidir con el terreno abonado por la pluma de Goytisolo en su novela.

A la dicotomía realidad/ficción hay que sumar la de pasado/presente, otra pareja conceptual que la televisión se ha encargado de liquidar a través de sus retransmisiones ininterrumpidas y su énfasis de lo oral y lo visual (Navajas 2002: 92), engendrando un presente transitivo, un tiempo sin principio ni fin (Imbert 2003: 25) que reclama la "[r]evancha de lo privado sobre lo público, del suceso sobre la Historia, de lo pragmático sobre lo programático, de lo vivencial sobre lo ideológico" (2003: 22), y que cuestiona el "discurso de la actualidad como modo de informar" y "los modos de narrar globalmente la realidad” (2003: 22). Así, ya es imposible poner a punto una ética de la información y todo se resuelve en el ámbito del collage (Baudrillard 2008: 72-73).

Goytisolo sigue los mismos derroteros ${ }^{11}$ y recurre en La saga de los Marx a lo que Ferré (2011a: 194) llama "un indeterminismo cuántico" en la cronología que le permite barajar hiperrealidad y simulación, logrando de este modo una línea temporal flexible en la que yuxtaponer los siglos XIX y XX (Ferré 2011b: 314315). No obstante, semejante estratagema, más que recusar el "tiempo capitalista"

10 El concepto de "flexi-narrative" es fundamental para entender las relaciones entre narratividad, televisión y mundo contemporáneo: "The flexi-narrative of series and serials can be regarded as reflecting the dynamic nature of television medium, and they have been argued to adequately 'reflect and respond to the increasing uncertainties and social ambiguities of the contemporary world" (Bednarek 2010: 12). Adriaensen (2007: 148) también, refiriéndose precisamente a La saga de los Marx, subraya cómo el medio televisivo parece absolutamente adecuado para reflejar el caos que caracteriza la década final del siglo XX.

11 "La saga de los Marx cuestiona de manera radical la posibilidad de acceder a la realidad, sistemáticamente mediatizada por los medios de comunicación" (Adriaensen 2007: 134). 
(Ferré 2011a: 204) ${ }^{12}$, obedece a unas idiosincrasias propias del autor, puesto que su escritura a menudo retoma elementos de un discurso performativo y ritual que si, por un lado, impone "al espectador una materialidad temporal y espacial que renuncia a su capacidad referencial para presentarse a sí misma, física e inmediata, vacía de contenido" (Cornago 2005: 48), por otro lado, "engendra una temporalidad circular y cerrada obtenida a través del presente continuo del acto de enunciación que se contrapone a una linealidad tendida entre pasado y futuro" (2005: 48). A este rasgo general se entrelazan las singularidades propias de La saga de los Marx, en cuyas páginas Goytisolo no solamente suspende el juicio histórico (Guillamón 1993: 51), sino que pone en duda la doxa de la Historia y la sume en un cíclico y constante devenir (Cornago 2005: 63), según una visión escéptica que desde siempre le ha hecho recelar de cualquier forma de certidumbre o dogmatismo ${ }^{13}$.

Otra pieza fundamental en la creación del fino engranaje goytisoliano es la de las citas, usadas habitualmente por el escritor:

como objetos textuales autónomos violentamente extraídos de los medios más diversos [que] irrumpen (...) de forma abrupta y traidora en el texto dinamitando su credibilidad, atravesando su unidad, sacrificada ahora en beneficio de un aparato textual que se ofrece a su libre utilización, puesta en escena de voces dispares, representación de discursos opuestos, juego caprichoso y traidor. La heterogeneidad de los elementos, su disposición alógica, la ausencia de un hilván que confiera un sentido y una unidad final, termina dinamitando la imposible ordenación de un cuerpo que se resiste a ser organizado, a ser informado, jerarquizado (...) para optar por la sufriente pero vitalista condición del devenir amorfo, revolucionario o paria (Cornago 2005: 70).

En efecto, en La saga de los Marx se agolpan de forma subrepticia pasajes de escritos (libros, ensayos, cartas personales, etc.) de y sobre Karl Marx ${ }^{14}$, los cuales, más allá de bosquejar un retrato del filósofo, contribuyen a fomentar la confusión entre realidad y ficción (Pérez Bowie 1996: 344) -nos enfrentamos a unos fragmentos de textos reales inscritos sin solución de continuidad en un marco ficcional-, y entre la Historia y el presente -en la mayoría de los casos, se trata de esquirlas descontextualizadas y enquistadas en un flujo atemporal de palabras-. Esta contaminación intertextual se ve implementada, además, por varias referencias al contexto audiovisual que, como ya hemos señalado, van, por ejemplo, de los fotogramas fellinianos a las imágenes en directo de los noticieros. Una heterogeneidad parecida a la que acabamos de describir, y trabada con la misma soltura - aunque no con la misma hondura-, es posible hallarla en la televisión, un medio que puede considerarse como una "gran casa de citas" en la que todo cabe (Imbert 2003: 59).

12 Por lo que hemos escrito hasta ahora consideramos que la afirmación de Ferré tendría validez si relacionáramos el tiempo descoyuntado goytisoliano exclusivamente con la ordenación temporal impuesta por un capitalismo industrial decimonónico, mientras que no podría aplicarse a una contemporaneidad regida por un(os) tiempo(s) mediático(s).

13 "Cuando leo libros de historia, la seguridad impertérrita con que sus autores establecen lo ocurrido hace milenios me produce una invencible sensación de incredulidad. ¿Cómo es posible reconstruir un pasado remoto si incluso el más reciente aparece sembrado de tantas incertidumbres y dudas?" (Goytisolo 1995: 38).

14 Aquí, por razones de síntesis, nos sería imposible mencionar todas las referencias intertextuales goytisolianas en $L a$ saga de los Marx. Para una exhaustiva panorámica remitimos al meticuloso ensayo de Marco Kunz (1997) La saga de los Marx, de Juan Goytisolo. Notas al texto, en el cual el estudioso intenta individuar el mayor número posible de citas, averiguando su procedencia y cotejándolas con los textos originales. 
La abundancia de guiños, más o menos explícitos, tanto en el discurso goytisoliano como en el televisivo, supone la existencia, al otro lado de la página o de la pantalla, de un sujeto activo dispuesto a interaccionar y a establecer conexiones. Los libros de Goytisolo constituyen siempre un reto para el lector (González Ortega 1999: 91; Cornago 2005: 52; Adriaensen 2007: 174) ${ }^{15}$, el cual, sobre todo a partir de Paisajes después de la batalla, está llamado a cooperar en la construcción del relato (Cornago 2005: 62), procedimiento que se repite puntualmente en La saga de los Marx (Guillamón 1993: 46; Pérez Bowie 1996: 343; Cornago 2005: 60). De hecho, una implicación tan apremiante del receptor en las obras del escritor barcelonés se debe, como apunta Cornago (2005: 38), a que su pluma acciona "unos mecanismos esencialmente performativos que articulan el texto como un sistema dinámico". El medio televisivo también interpela a su destinatario y le invita a participar (González Requena 1999: 48; Imbert 2003: 68), puesto que le demanda una respuesta interpretativa a la pluralidad y a la disparidad de mensajes transmitidos (González Requena 1999: 26).

Sin embargo, esta narrativa generada por una suerte de metacoherencia obtenida a través de un conjunto de partes, no necesariamente ligadas por una proximidad lógica o temática (Corner 1999: 51), a menudo se reduce a una pura relación estética del telespectador con lo visto, menguando así su capacidad de distanciamiento crítico y de compromiso (1999: 51). La tentación de bajar la guardia procede de la naturaleza fundamentalmente consumista del acto de ver la televisión, lo cual se resuelve en el prevalecer de la dimensión escópica sobre la comunicativa (González Requena 1999: 52). Por ende, los textos de Goytisolo tienen una recaída activa en la mente del lector y lo espolean a convertirse en su cómplice, mientras que la pantalla se presenta como un espectáculo y la performatividad se diluye en una performance replegada sobre sí misma (Wallace 1998: 23), que requiere una menor participación al aprovechar el elemento audiovisual para captar el interés del espectador ${ }^{16}$.

El autor de La saga de los Marx explota la permeabilidad de su escritura para adueñarse del discurso propio de la televisión, precisamente para cortocircuitar haciendo hincapié en ese resquicio entre performatividad y performance- la que a primera vista podría tomarse como una perfecta superposición de lenguajes y, al adaptarlo a un texto que muestra de forma descarada su artificiosidad literaria, sondea uno de los caminos posibles para retratar nuestra época tan influida por los media y la idea de simulacro:

La alternativa a la crisis de la representación que amenaza el horizonte cultural contemporáneo desde finales del siglo XIX (...) consiste (...) en la focalización de las estrategias y dispositivos que hacen funcionar estas maquinarias (...), en una política

El mismo autor, en un artículo de 1982, reivindicaba la necesidad de recuperar la figura del receptor avispado que había caracterizado a los intelectuales bajo el régimen franquista: "En la época de Franco, había surgido un tipo de lector atento, avezado al arte de leer entre líneas y descubrir intenciones ocultas y mensajes en clave. Hoy, esa lectura activa y cómplice no existe; el público sólo capta lo evidente, se queda en la superficie de lo escrito" (Goytisolo 1982: 16).

16 Adriaensen enfoca la cuestión de manera parecida, aunque se limite exclusivamente a los mecanismos que atañen a la ironía en La saga de los Marx: "La ironía 'televisiva' (...) le otorga al espectador una posición cómoda, de superioridad con respecto a la imagen parodiada. Se establece una suerte de dicotomía que le permite al espectador adoptar una posición hasta cierto punto exterior a la imagen representada. En el caso de la ironía cervantina de $L a$ saga de los Marx, en cambio, tal distanciamiento es imposible porque los diferentes planos de la narración no se distinguen claramente y el lector no puede distanciarse de ninguno, sino que se ve obligado a 'navegar' entre varios" (2007: 226). 
centrada en los mecanismos performativos, en el cuerpo de la propia escritura en funcionamiento, antes que en sus resultados finales, en el ejercicio de la puesta en escena antes que en la representación (Cornago 2005: 71).

En este sentido son significativas las digresiones que introduce el narrador a propósito de la novela que está redactando, unos pasajes en los que un editor de aspecto faulkneriano y devoto a un realismo plañidero de raigambre dickensiana critica la estrafalaria osadía estructural de ese manuscrito (Goytisolo 2005: 73-77), que coincidiría con el que el lector tiene entre las manos (pp. 162-163). Los reproches del empresario y la precaria situación económica del cronista objeto de las quejas, empujan a este último a insertar observaciones cáusticas que desvelan las técnicas efectivamente empleadas para componer el rompecabezas narrativo de La saga de los Marx. He aquí dos breves muestras:

A fin de curarte en salud y evitar los comentarios sarcásticos del editor después de una lectura que podría poner en peligro el tenue hilo de las mensualidades merced a las cuales vivías durante la compostura del libro, decidiste enviarle por correo unas cuartillas con un retrato físico-moral de Marx y una descripción minuciosa de su domicilio, con todos los ingredientes de un informe policial o de un novelista discípulo de Balzac, conocedor asimismo de la obra de Dickens, la tarea era fácil bastaría para ello echar mano de algunos de los testimonios de quienes le frecuentaron, copiarlo con esmero y mandarlo al editor como presunta muestra de tu trabajo ¡en vez del auténtico y perturbador manuscrito! (Goytisolo 2005: 77) ${ }^{17}$.

¡Cielos, habías vuelto de nuevo a las andadas, multiplicado en situaciones inverosímiles, entreverado espacios y tiempos, seguido el camino de tu imaginación desbocada, prolongado el impublicable manuscrito! (Goytisolo 2005: 96) ${ }^{18}$.

Con la misma transparencia con la que pone al descubierto los artilugios que subyacen a la narración, Goytisolo delata lo que se oculta detrás de las imágenes televisadas del serial La Baronne Rouge ${ }^{19}$, espectáculo audiovisual protagonizado por la familia Marx, que en la tercera sección del libro se contrapone, con su evidente atractivo comercial, al alambicado escrito tan denostado por el editor faulkneriano.

El constante esfuerzo por subrayar el estatus ficcional de la novela y, dentro de ésta, del medio televisivo (Adriaensen 2007: 222), logra romper ese círculo vicioso

17 En estas páginas Goytisolo no se limita a ridiculizar el ansia de realismo de ciertos editores y escritores, sino que, en un juego absolutamente paradójico, de verdad copia la descripción de Marx y de su domicilio elaborada por el espía prusiano Stieber en su informe sobre el filósofo que entregó a su gobierno (Goytisolo 2005: 78). Este hecho, además, desmiente la afirmación anterior del narrador, según la cual ese documento no aparecería en el libro verdadero y constituiría sólo una triquiñuela para congraciarse con quien le pagaba sus mensualidades. Sin embargo, semejante contradicción no sorprende, ya que el autor en La saga de los Marx había hecho -y hará- lo mismo en repetidas ocasiones, sin explicitarlo: por ejemplo, a la hora de trazar un escueto retrato de Bakunin usa las palabras de Alexander Herzen en Mein Leben (Kunz 1997: 14), o en el caso del mismo Marx transcribe las impresiones de Albert Brisbane, un periodista de la New York Daily Tribune que en 1848 había visitado al autor del Capital (1997: 29).

18 Se trata obviamente de una falsa autocrítica que manifiesta claramente cómo ha sido concebida la novela.

19 Véase la tercera parte de la novela (Goytisolo 2005: 129-151), contrapunteada de constantes interrupciones de la acción del baile organizado por la familia Marx en Modena Villas para llamar la atención de quien lee sobre la presencia de un equipo de rodaje que está grabando las escenas (p. 129), o sobre la figura de un director que imparte instrucciones a los técnicos y a los actores (pp. 135, 137-138, 140), o sobre el guion del serial (pp. 130-131, 147, 150, 151). 
al que parecía condenada cualquier tentativa de pasar la pequeña pantalla -uno de los medios autoirónicos por antonomasia (Wallace 1998: 35)- por el tamiz de la ironía, porque en la mente del lector se produce una reacción crítica que le obliga a fijarse en los elementos textuales y a redescubrir su centralidad, provocando una respuesta que podríamos explicar adaptando unos razonamientos de Slavoj Žižek sobre el arte contemporáneo. El filósofo esloveno, al analizar la relación que se establece entre museo y objeto expuesto en él, pone el acento sobre la reciprocidad de dicho vínculo: los ready made duchampianos, o los más recientes productos trash, adquieren un barniz artístico simplemente en función del entorno en que están sumidos, porque ese desfase entre la sacralidad del lugar y la insignificancia o la aberración estética de la obra exhibida rescata el orden simbólico representado por el espacio museístico (Žižek 2013: 36-38). Frente al urinario de Duchamp la mayoría de las personas se pregunta cómo es posible que un mingitorio merezca lucir su pragmático diseño en una sala de exposiciones, pero al plantearse la cuestión, inconscientemente, están reconstruyendo por sus adentros el concepto mismo de museo.

Ahora bien, en La saga de los Marx, el lector, al toparse reiteradamente con el televisor -ready made u objeto trash de la sociedad posmoderna- por entre las sinuosidades de una escritura densa y marcada por unos ardides metaficcionales, se ve constreñido a reflexionar sobre el artefacto textual tanto con respecto a su funcionamiento como a su valor simbólico, o sea, sobre lo literario. Goytisolo cumple así con su compromiso de introducir "los estereotipos y mediatizaciones de aquella [la tecnología] en el ámbito de la novela, invirtiendo los papeles y subordinando las cotidianas irrupciones televisivas y sus mensajes subliminales a las reglas del campo de maniobra abierto por Cervantes" (Goytisolo 2005: 176-177).

La recuperación de las potencialidades de la ficción literaria propicia también un rescate de la Historia, la cual logra sustraerse a las trampas del revival "entendido como imposible reinscripción de lo ocurrido en un ámbito de actualidad totalitaria" (Fernández Porta 2008: 57), y a superar los límites de una "historia (...) enlatada y sellada al vacío de cara a un destinatario futuro" (Ferré 2011b: 288), precisamente por medio de la controvertida figura de Karl Marx, porque ésta, remedando la contraposición entre televisión y escritura, funciona como reactivo con respecto al contexto televisivo y televisado en el que está anacrónicamente insertada. Su presencia y su connotación profundamente histórica (Pérez Bowie 1996: 340), a pesar del -o gracias al- prisma lúdico goytisoliano, contrastan con el entorno atemporal e inducen a quien lee la obra -alguien que sin duda no ignora la efectiva existencia de Marx en un determinado periodo del pasado ${ }^{20}$ - a dotar de sentido a ese tiempo difuminado, y a reconstruir críticamente un hilo cronológico (Adriaensen 2007: 142) que va desde los orígenes del pensamiento marxista hasta su crisis a comienzos de los años 90.

\footnotetext{
No hay que olvidar que en un irónico juego de espejos entre realidad y ficción, Goytisolo (2005: 9) pone al comienzo de La saga de los Marx un apartado que por su encabezamiento, "Dramatis personae", parece un guiño al universo ficcional del teatro, pero que a través de los nombres citados en él, todos reales e indicados como si fueran voces de una enciclopedia, remite claramente al ámbito histórico. De esta forma consigue que los lectores que saben quién fue Karl Marx -la mayoría- sonrían frente a su condición de personaje "ficticio" dentro de una "representación teatral", mientras que los que desconocieran su existencia -sin duda, una minoría- se verían envueltos en una situación de incertidumbre al no entender en qué contexto colocarle: si en las páginas de una obra de teatro o en las de un diccionario enciclopédico. A esto hay que añadir la "Noticia biográfica de personajes históricos citados en la obra" (p. 199) y la "Breve bibliografía consultada" (p. 203) que cierran el texto y refuerzan "el carácter factual del relato insistiendo en su condición de producto de una tarea investigadora, sobre la obra de ficción" (Pérez Bowie 1996: 341).
} 
Es el moderador José Luis Balbín quien, en el preámbulo al talk show que ocupa el cuarto capítulo de La saga de los Marx, ofrece una clave de lectura para abordar desde una perspectiva múltiple al teorizador del comunismo" : "profeta, genio, embaucador, erudito sediento de poder, hombre entregado con generosidad a la defensa de los explotados o todas esas cosas a un tiempo, ¡la personalidad de Marx no deja indiferente a nadie y será debatida a continuación por los invitados aquí reunidos!" (Goytisolo 2005: 162). Éstos son los rasgos que también Goytisolo incluye en su novela y constituyen el material histórico lagunoso que el narrador no logra -o más bien no quiere- ordenar (Pérez Bowie 1996: 340) y que, irónica y paradójicamente, tanto en el tiempo presente del debate televisivo como en el del texto, invitan al "espectador"22 y al lector a organizar "la información ofrecida, suturando fragmentos desgajados y supliendo las elipsis. Y así puede llegar a reconstruir la trayectoria biográfica del personaje" (1996: 343).

La faceta personal de Marx, luego, no puede desligarse de sus convicciones ideológicas y, entonces, el simulacro de la discusión mediática y los mecanismos metaficcionales del libro evidencian la parcialidad de las opiniones, las elisiones (in) voluntarias y, sobre todo, cómo una teoría filosófico-política con hondas raíces en el siglo XIX repercute en una contemporaneidad marcada por la emigración y unos desajustes sociales que tocan muy de cerca el mundo occidental liberista. Quienquiera que lea La saga de los Marx, pues, se verá impelido a tomar conciencia del hecho de que la caída del muro de Berlín no ha traído consigo el final de la Historia ${ }^{23}$, como teorizó Fukuyama, sino que ésta sigue su curso (Pérez Bowie 1996: 348) y, a pesar de la labilidad de los instrumentos hermenéuticos de los que disponemos, es necesario conocer sus entretelas para ejercer una mirada crítica sobre ella ${ }^{24}$.

$21 \quad$ Balbín, como recuerda Kunz (1997: 150), es un periodista de carne y hueso que dirigió, desde mediados de los años setenta hasta 1985, y luego de 1990 a 1993, un programa de televisión que se llamaba La clave, nombre muy significativo que Goytisolo (2005: 160) retoma en su libro, mezclando otra vez realidad y ficción. Además, una de dichas transmisiones, en noviembre de 1979, después de la proyección de la película La clave del enigma -filme que reemplazó La confesión, un docudrama sobre las purgas estalinistas que no pudo ser transmitido por una huelga de los dobladores españoles- había sido dedicada al pensamiento marxista, y fue bastante sonado el enfrentamiento que tuvo lugar entre el secretario del PCE Santiago Carrillo y el filósofo francés Bernard-Henry Lévi. Es posible ver el debate conectándose al enlace http:/www.youtube.com/watch?v=VLo9LajdKnQ, y es fácil averiguar que hay algunos pasajes que recuerdan fragmentos del texto goytisoliano, como, por ejemplo, el que se centra en el tema del colonialismo (Goytisolo 2005: 172-173), y que remite a una acalorada discusión entre Lévi y el filósofo marxista Roger Garaudy. En el libro de Goytisolo se reproducen tan fielmente las pautas reales del programa La clave que incluso hay un espacio dedicado a la tanda de preguntas finales por parte de los televidentes.

22 A lo largo del talk show el narrador prácticamente no intervendrá nunca para ofrecer su punto de vista o para brindar una opinión crítica o que pueda conciliar las posiciones de los demás contertulios.

23 “¡créame la Historia no se ha acabado aún por mucho que sostengan lo contrario los modistas y diseñadores de ideas! ¿ignoran de verdad esas cabezas huecas el mundo criminal en el que viven, la espiral de desastres que les absorberá de una vez? ¡Déjelos, déjelos pontificar a su gusto en sus cátedras televisivas et rira bien qui rira le dernier!” (Goytisolo 2005: 108)

24 Esta forma de "reactivar" el sentido de la Historia es afín al modo en que Goytisolo concibe su peculiar escritura, un tema muy debatido entre quienes lo consideran un escritor más bien posmoderno (González Ortega 1999: 93; Cornago 2002: 97; Ferré 2011b: 302-303) y quienes lo sitúan en el marco de la modernidad (Llored 2009b: 41), diatriba que incluso engendró un dossier sobre dicha cuestión, publicado en 2009 en el número 312 de la revista Quimera. Todas las opiniones a favor o en contra de una u otra postura se basan en argumentos sólidos y no parecen ofrecer otra salida más allá de la imposibilidad de encasillarle en uno u otro bando (Kunz 2009b: 26; Adriaensen 2007: 303 y 2009: 31) o, tal vez, definirle solomónicamente como un (pos)moderno y, sin embargo, es justo esa ambigüedad la cifra de su literatura, la cual quizás se podría explicar a partir de unas palabras usadas por Manuel Vázquez Montalbán para definir su propia obra: "Yo reconozco la validez de la posmodernidad precisamente en lo que tiene de reconocimiento de la validez de todos los códigos hasta que no demuestren su invalidez y creo que esta 
Las dificultades en la tarea de relacionarse con los personajes, los acontecimientos históricos y su sentido, más allá de la parcialidad implícita en la mirada subjetiva de todo historiador, podrían achacarse al hecho de que también a través de las imágenes de la grande y la pequeña pantalla "[h]emos pasado de una memoria unánime a la memoria polémica" (Lipovetsky y Serroy 2009: 180), que lo pone todo en entredicho por medio de una libertad de expresión que si, por un lado, es más que saludable, por otro lado, acarrea cierta confusión a causa de la inmediatez y del alud de noticias y de las reelaboraciones de sucesos, lo cual nos sitúa frente a un "universo infinito" (2009: 146). Una visión tan fraccionada y poliédrica ha influido a fondo en aquellas prácticas artísticas que asumen el desafío de representar y examinar personalidades o acontecimientos reales más o menos cercanos en el tiempo ${ }^{25}$, fomentando en la novela histórica posmoderna una ruptura de la barrera ontológica "entre el mundo como creemos que fue y el mundo posible de la ficción” (Lozano Mijares 2007: 158), y resquebrajando en los ámbitos cinematográficos y televisivos el anticuado discurso pedagógico del documental (Lipovetsky y Serroy 2009: 146) que ha dejado de someter al espectador a un "aprendizaje casi académico de un mundo conocido", para enfrentarlo a una "investigación crítica de un mundo liberado y sin fronteras" (2009: 146).

A la luz de lo escrito hasta ahora quizás convendría releer entonces las relaciones paródicas que establece el texto goytisoliano entre escritura y medios audiovisuales, no sólo dentro de la estética fílmica (Ribeiro de Menezes 2005: 130) o del serial (Ferré 2011b: 306), sino que se podría enfatizar su cercanía al reportaje (Guillamón 1993: 50; Ferré 2011b: 309), puesto que los pilares de carga de este formato son la polifonía (Gordillo 1999: 51), un orden cronológico no lineal montado según una precisa voluntad dramática (1999: 52) y, por fin, la figura de un reportero-informador que "se sitúa en un presente simultáneo al de la recepción del discurso" (1999: 53), tiempo este último que coexistiría anacrónicamente con unas interferencias del pasado (1999: 53) ${ }^{26}$ en un discurso donde coinciden la temporalidad de lo contado con la de la narración (Imbert 2003: 85).

Nos encontramos, pues, frente a las piedras angulares de La saga de los Marx que hemos venido resumiendo en nuestro artículo ${ }^{27}$. Sin embargo, se podría extremar el juego de hibridaciones y pasar sin esfuerzo alguno del reportaje al documental e

disposición es precisamente la vanguardista hoy y aquí. No reconozco en cambio la validez de la ahistoricidad del discurso posmoderno que enmascara, en mi opinión, una interesada instalación política en el final de la Historia" (Colmeiro 2013: 135). Si el rechazo de esa ahistoricidad lo aplicáramos también al ámbito de la historia literaria, conseguiríamos enfocar de forma más clara las señas de identidad de Goytisolo, puesto que él adopta a menudo códigos posmodernos, pero sin renunciar a una sensibilidad moral y artística que tiene sus raíces en una profunda tradición cultural de ruptura, empleando frecuentemente los primeros para reivindicar esta última (Ridao 2006: 213). De hecho, uno de los objetos principales de las críticas del autor de La saga de los Marx a la postura posmoderna es la pereza intelectual de ésta: "En particular, Goytisolo reprocha a los intelectuales escritores e intelectuales posmodernos su ignorancia de la realidad histórica y del árbol de la literatura” (Adriaensen 2007: 175).

25 "La historia para los posmodernos es, en fin, una metanarración más, [que] ha de ser sustituida por la intrahistoria, por microrrelatos que no utilizan una marcha ascendente, sino discontinua, asincrónica, llena de direcciones múltiples e incertidumbre" (Lozano Mijares 2007: 162).

26 El reportaje, en general, teje unos lazos más estrechos con la actualidad con respecto al documental, porque su origen se sitúa en el ámbito de las revistas ilustradas (Gordillo 1999: 50).

27 En este contexto nos parece oportuno destacar sobre todo el carácter "heterofónico" y "heteroglósico" del texto goytisoliano (Pérez Bowie 1996: 342-343), ya que las cuestiones relacionadas con el desorden temporal del escrito y la omnipresente figura del narrador han sido reiteradamente tratadas a lo largo del presente artículo. 
incluso al docudrama, modalidades interpretativas muy permeables que difuminan las fronteras entre los géneros (Lipovetsky y Serroy 2009: 161) e "inventa[n] crecientes combinaciones inéditas 'realidad-relato': reaviva[n] y vuelve[n] a poner sobre la mesa el problema de la ficción planteando el de la propia realidad" (2009: 162). Debido a estas características, la mayoría de los documentales de las últimas décadas apuestan por una mirada desmitificadora (2009: 150), militante (2009: 157), pero sin imponer una lectura unívoca e incuestionable:

el neodocumental refleja el deseo individualista de ser más participativo y autónomo, menos controlador, de estar menos orientado por el hilo de la trama narrativa (...). Una parte del goce del espectador reside entonces en esta libertad de la imaginación subjetiva que recompone, para uso privado, un relato más personal, más secreto, a través de la realidad que se le presenta (2009: 152).

Si luego nos centramos en el documental televisivo ${ }^{28}$, además de reconocer dichos atributos, volveremos a toparnos con la viva voz de un presentador-reportero, a menudo intradiegético, que se inmiscuye dramáticamente dentro de la narración y que se yergue en sujeto explícito de la enunciación, a tal punto que

el documental televisivo debería denominarse gran reportaje, ya que no renuncia al fenómeno de interpelación al espectador real, sumando las funciones fática y conativa a la función exclusiva en el género: la referencial (...). Por otro lado, la función expresiva también tendría un gran protagonismo, ya que el narrador impregna -en muchos casos- de elementos de subjetividad el relato, dominado entonces por la focalización interna (Gordillo 1999: 48).

Resulta casi superfluo evidenciar las afinidades entre este profesional de los medios audiovisuales y el narrador-cronista que Juan Goytisolo inserta en La saga de los Marx, alguien que selecciona el lenguaje, organiza a su antojo el material narrativo, y desempeña un papel central dentro de la misma acción al entrevistarse con diferentes personajes históricos -el anarquista Anselmo Lorenzo, Bakunin, etc.y ficcionales -el editor, el asesor, Miss. Lewin-Strauss, etc.-, o al apremiar a los componentes de la familia Marx -Jenny y Lenchen- para que le revelen sus opiniones o traten de justificar sus actos y su fidelidad a la doctrina elaborada por el patriarca $\operatorname{Karl}^{29}$.

Gracias al trato directo que de forma sorprendente se establece entre quien narra y unas personalidades que pertenecieron al siglo XIX, es posible dar un paso hacia el docudrama, género espectacular -en la doble acepción del términoque podríamos colocar a mitad de camino entre el documental y el cine histórico

28 El documental televisivo, como es lógico, es heredero del documentalismo cinematográfico (Gordillo 1999: 46), sin embargo, hay que tener en cuenta que la televisión ha contaminado, con su fragmentarismo y su rapidez, el cine (Lipovetsky y Serroy 2009: 222), produciendo una nueva estética documentalista, más desenfadada, dinámica, heterogénea y espectacular -cuyo reflejo en el libro de Goytisolo podría ser el rápido montaje del primer capítulo (2005: 13-69)-, hoy en día perfectamente representada por los trabajos del director estadounidense Michael Moore.

29 Adriaensen destaca que "La novela de Goytisolo tiene una estructura polifónica en la cual el narrador (y autor ficticio de la novela) adopta el papel de dirigente, con cierta visión sobre la problemática pero sin convertirse en un personaje con una psicología o una identidad elaborada" (2007: 79) y, más adelante, llega incluso a definir la labor de quien narra como una "puesta en escena" o "puesta en plató" (2007: 146). 
hipermoderno: del primero toma el afán por brindar una representación verosímil de la realidad, mientras que del segundo aprovecha su afición por "presentizar" el pasado (Lipovetsky y Serroy 2009: 168) ${ }^{30}$ y su tendencia a borrar cualquier marca de superioridad del héroe, convirtiéndolo en homo simplex (2009: 171). De semejante fusión se obtiene un espectáculo que encandila a los televidentes, combinando entre sí diferentes recursos:

El docudrama resulta ser (...) una de las fórmulas discursivas que presentan mayor eficacia en varios frentes: en cuanto a la verosimilitud, a la posibilidad de presentar la actualidad, la capacidad narrativa y la captación de la atención del espectador, lo que reinvierte de forma directa en la audiencia. Es un género televisivo caracterizado por la reconstrucción y dramatización de acontecimientos reales interpretados por sus auténticos protagonistas o por actores no profesionales. (...) Este género está dotado de una enunciación subjetiva y de una clara inscripción del presente de la enunciación (Gordillo 1999: 79).

El capítulo tercero de La saga de los Marx (Goytisolo 2005: 125-151), en cuyas páginas se representa el baile de Modena Villas dentro del marco del serial $\mathrm{La}$ Baronne Rouge, es paradigmático de este tipo de aproximación sensacionalista, y ahí el narrador goytisoliano reúne en sí la doble función de espectador y de presentadorinformador: si por un lado es un invitado-intruso que fisgonea en las habitaciones y por entre los decorados -el docudrama es siempre una reconstrucción artificiosa que en general se focaliza en acontecimientos privados, acrecentando la morbosidad del público al concederle el privilegio de la visión sesgada del voyeur (Gordillo 1999: 80)-, por otro lado es un conductor-reportero que no desdeña entrevistarse con Marx $^{31}$ - o con el actor que lo interpreta- (Goytisolo 2005: 138-140), y que ilustra a sus lectores-espectadores fragmentos pasados y futuros de las vidas de las hijas de Jenny -acompañados incluso por una voz en off, una banda sonora y unas escuetas declaraciones de George Bernard Shaw y Karl Kautsky (p. 144)- en unas pantallas gigantes que, al accionarse un proyector de diapositivas, se iluminan en los cuartos de Laura (pp. 132-135), de Jennychen (pp. 135-138) y de Tussy (pp. 141-145, 149). Luego se adentrará también en lo que parece el despacho del autor del Capital (pp. 145-147), aunque el maniquí sentado al escritorio y el aspecto acartonado de la pieza confieran al ambiente un inequívoco aire postizo de escenografía cuidadosamente estudiada para ocupar un plató televisivo, bajo los focos del cual se mueve quien narra, ensartando preguntas sobre el fundador del socialismo científico, como si fuera un locutor que ofreciera el avance de un programa dedicado a Karl Marx, casi un tráiler de La Clave - de ese debate que ocupará la sección siguiente del libro-, que se

30 En La pantalla global. Cultura mediática y cine en la era hipermoderna, Lipovetsky y Serroy (2009: 168) subrayan de manera específica la actualización del pasado mediante el empleo de un lenguaje contemporáneo que contrasta con la supuesta historicidad de lo filmado. Este aspecto aparece también en el volumen de Goytisolo, donde el autor lo lleva incluso al absurdo, poniendo por ejemplo en la boca de Jenny Von Westphalen la expresión "virus informático" (2005: 32), sin contar el hecho de que en casa de los Marx hay un televisor con un mando a distancia (2005: 20).

31 A la luz de estos detalles no sería disparatado hipotizar que, junto a las libertades imaginativas concedidas por la pluma, el escritor, a la hora de recrear el cochambroso hogar de los Marx de Dean Street (Goytisolo 2005: 85-91) o en el diálogo final con Lenchen en el cementerio de Highgate (pp. 187-193), haya podido explotar socarronamente elementos derivados de este tipo de entretenimiento televisivo. 
cierra con una aparatosa danza macabra y una alocución admonitoria (p. 151) cuya autoría, pese a las dudas, recae forzosamente en el narrador ${ }^{32}$.

Otra vuelta de tuerca la da Goytisolo al parodiar, en la cuarta parte de su escrito, los mecanismos del talk show, de esa lidia verbal entre ánimos enconados que es una de las (per)versiones posibles del docudrama (Gordillo 1999: 84), en la que se asiste a la espectacularización del habla (Imbert 2003: 123) como ejercicio retórico de prevaricación de los demás:

La lógica que impera aquí es antitética (de oposiciones irreductibles), la moral es maniquea y la lección es de poder, encerrando una enorme violencia simbólica: para hacer valer las ideas hay que imponerse (...) al otro, de ahí las voces, los gritos, los soliloquios, las interrupciones, los solapamientos de discursos que se producen continuamente en estos debates llevando a cabo, hasta su caricatura, la asimilación entre palabra y acción (2003: 185).

Las posiciones contrapuestas y marcadamente parciales esgrimidas por cada uno de los participantes, de hecho, contribuyen a derribar cualquier atisbo de objetividad y borran de antemano la ilusión de un análisis imparcial de los acontecimientos y, en el caso concreto del texto goytisoliano, de la Historia y de la personalidad de Marx, ratificando la imposibilidad de un enfoque aséptico y ordenador del caos, y llevando a las extremas consecuencias, hasta su atomización, el modelo interpretativo esbozado por quien narra, lastrado por incertidumbres, dudas, citas de escritos dispares y contradictorios en sus juicios sobre el filósofo de Tréveris que impiden la construcción de un relato coherente ${ }^{33}$. El talk show, pues, mina de forma radical la supuesta pretensión de imparcialidad que subyace al documental y funciona, en la contaminación entre aspectos audiovisuales y literarios, como ulterior complemento del proceso destructor y cuestionador de la escritura de Goytisolo.

Si el autor barcelonés en La saga de los Marx se proponía desarticular el relato histórico (Pérez Bowie 1996: 339), y dinamitar unas estructuras de pensamiento del siglo XIX enraizadas en un realismo que produce novelas históricas sin fisuras o crónicas biográficas monolíticas (Ferré 2011a: 190) en escasa consonancia con una contemporaneidad mediática (2011a: 280), lo consigue por medio de una literatura irónicamente permeable a la televisión que, como hemos mostrado a lo largo del presente artículo, no es un elemento marginal, sino uno de los fulcros del volumen al proporcionar un lenguaje y unos nuevos géneros expresivos y narrativos capaces de hibridarse con lo literario, gracias a una reciprocidad ya puesta en evidencia por Foster Wallace (1998: 34), sin los cuales no hubiera sido posible una lectura tan transversal, actual y polifacética de Marx y de la sociedad occidental de nuestro tiempo.

22 "(¿quién habla? ¿tú? ¿una misteriosa voz en off? ¿o figura el discurso en el guión de La Baronne Rouge?) Por triste que sea, deberás aceptar la evidencia, sólo el desorientado autor de estas páginas deambula en el escenario vacío de Modena Villas sin saber cómo redactar de acuerdo a los cánones de la crítica y gusto del público (...) ¡su dichosa e imposible novela!" (Goytisolo 2005: 151). En esta cita encontramos por enésima vez un salto de lo audiovisual a lo metaficcional, que obliga al lector a centrarse en la naturaleza textual y literaria de la obra que tiene entre las manos.

33 "arrojaste bolígrafo y borradores a la cesta de papeles ¡todo había sido un error! ¡Nunca escribirías La saga de los Marx!" (Goytisolo 2005: 198). 


\section{OBRAS CITADAS}

Adriaensen, Brigitte. 2007. La poética de la ironía en la obra tardía de Juan Goytisolo (19932000). Arabescos para entendidos. Madrid: Verbum.

. 2009. "Cinco razones para explicar por qué Goytisolo (no) es un escritor posmoderno". Quimera 312: 28-32.

y Marco Kunz. 2009. Pesquisas en la obra tardía de Juan Goytisolo. Amsterdam: Rodopi.

Abruzzese, Alberto y Andrea Miconi. 2002. Zapping. Sociología de la experiencia televisiva. Madrid: Cátedra.

Almela, Margarita. 1996. "A vueltas con la historia: La saga de los Marx, de Juan Goytisolo". En Romero Castillo, José, Francisco Gutiérrez Carbajo y Mario García-Page (Eds.), La novela histórica a finales del siglo XX. Actas del V Seminario Internacional de Instituto de Semiótica Literaria y Teatral de la UNED. Madrid: Visor. 127-134.

Baudrillard, Jean. 2008. El pacto de lucidez o la inteligencia del mal. Buenos Aires: Amorrortu.

Bednarek, Monika. 2010. The Language of Fictional Television. Drama and Identity. London: Continuum.

Camacho, José María. 1993. "Juan Goytisolo dice que la sociedad española 'está lobotomizada y babea frente al televisor"'. $A B C 23$ de febrero de 1993: 57.

Colmeiro, José. 2013. El ruido y la furia. Conversaciones con Manuel Vázquez Montalbán desde el planeta de los simios. Madrid: Iberoamericana.

Cornago, Óscar. 2002. "Historia de la locura en la época posmoderna: El viaje esquizoide de Juan Goytisolo". ALEC 27.2: 95-130.

.2005. Resistir en la era de los medios: Estrategias performativas en literatura, teatro, cine y televisión. Madrid: Iberoamericana.

Corner, John. 1999. Critical Ideas in Television Studies. Oxford: Clarendon Press.

Davis, Stuart. 2009. "El lugar de las novelas tardías en la obra completa de Juan Goytisolo". En Adriaensen, Brigitte y Marco Kunz (Dirs.), Pesquisas en la obra tardía de Juan Goytisolo. Amsterdam: Rodopi. 23-42.

Debord, Guy. 1995. La sociedad del espectáculo. Santiago de Chile: Ediciones Naufragio.

Fernández Porta, Eloy. 2008. Homo Sampler. Tiempo y consumo en la Era Afterpop. Barcelona: Anagrama.

Ferré, Juan Francisco. 2011a. "Re-escribiendo la historia como simulacro: La utopía del texto y La saga de los Marx". En Ferré, Juan Francisco, Mímesis y simulacro. Ensayos sobre la realidad (del Marqués de Sade a David Foster Wallace). Málaga: E.D.A. Libros. 183-208. 2011b. "Zona cero. El simulacro virtual como sucedáneo metaliterario de la narrativa contemporánea”. En Ferré, Juan Francisco, Mímesis y simulacro. Ensayos sobre la realidad (del Marqués de Sade a David Foster Wallace). Málaga: E.D.A. Libros. 279-328.

González Ortega, Nelson. 1999. "Juan Goytisolo y la (de)construcción del lenguaje literario moderno y de la sociedad española posmoderna". En Enkvit, Inger (Ed.), Un círculo de relectores. Jornadas sobre Juan Goytisolo. Almería: Instituto de Estudios Almeriensies. 87-100.

González Requena, Jesús. 1999. El discurso televisivo: Espectáculo de la posmodernidad. Madrid: Cátedra.

Gordillo, Inmaculada. 1999. Narrativa y televisión. Alcalá de Guadaira: Mad.

Goytisolo, Juan. 1982. "Sobre literatura y vida literaria". Quimera 23: 16-21. 1995. Coto vedado. Barcelona: Grijalbo Mondadori.

2005. La saga de los Marx. Barcelona: El Aleph.

Guillamón, Julià. 1993. "Fellini por Goytisolo: La saga de los Marx". Quimera 121: 46-53.

Imbert, Gérard. 2003. El zoo visual. De la televisión espectacular a la televisión especular. Barcelona: Gedisa. 
Kunz, Marco. 1997. La saga de los Marx, de Juan Goytisolo. Notas al texto. Basel: Romanisches Seminar (ARBA 7).

2009a. "Contra los discursos totalitarios: En torno a la intertextualidad marxista y fascista en La saga de los Marx y Las semanas del jardín". En Adriaensen, Brigitte y Marco Kunz (Dirs.), Pesquisas en la obra tardía de Juan Goytisolo. Amsterdam: Rodopi. 89116.

2009b. "Juan Goytisolo y la posmodernidad". Quimera 312: 26-27.

Lipovetsky, Gilles y Jean Serroy. 2009. La pantalla global. Cultura mediática y cine en la era hipermoderna. Barcelona: Anagrama.

Lozano Mijares, María del Pilar. 2007. La novela española posmoderna. Madrid: Arco Libros.

Llored, Yannick. 2009a. Juan Goytisolo. Le soi, le monde et la création littéraire. Villeneuve D’Ascq: Presses Universitaires du Septentrion. 2009b. "Las señas del sentido en la escritura de Juan Goytisolo". Quimera 312: 40-45.

Machado, Arlindo. 2009. El sujeto en la pantalla. La aventura del espectador, del deseo a la acción. Barcelona: Gedisa.

Mora, Vicente Luis. 2012. El lectoespectador. Barcelona: Seix Barral.

Navajas, Gonzalo. 2002. La narrativa española en la era global. Barcelona: EUB.

Pérez Bowie, José Antonio. 1996. "¿La inviabilidad de la novela histórica? La saga de los Marx, de Juan Goytisolo”. En Romero Castillo, José, Francisco Gutiérrez Carbajo y Mario García-Page (Eds.), La novela histórica a finales del siglo XX. Actas del V Seminario Internacional de Instituto de Semiótica Literaria y Teatral de la UNED. Madrid: Visor. 337-349.

Reig, Ramón. 2009. "Comunicación masiva e industrias culturales”. En Gracia, Jordi y Domingo Ródenas de Moya (Eds.), Más es más. Sociedad y cultura en la España democrática, 1986-2008. Madrid: Iberoamericana. 71-92.

Ribeiro de Menezes, Alison. 2005. Juan Goytisolo. The Author as Dissident. Woodbridge: Tamesis.

Ridao, José María. 2006. "La huella de la heterodoxia”. En Ridao, José María, Elogio de la imperfección. Barcelona: Círculo de Lectores/Galaxia Gutenberg. 205-218.

Rueda Laffond, José Carlos y María del Mar Chicharro Merayo. 2006. La televisión en España (1956-2006). Política, consumo y cultura televisiva. Madrid: Fragua.

Shirky, Clay. 2011. Cognitive Surplus. How Technology Makes Consumers into Collaborators. New York: Penguin Books.

Wallace, Foster David. 1998. "E unibus pluram. Television and U.S. Fiction". En Wallace, Foster David, A Supposedly Fun Thing I'll Never Do Again. Back Bay: New York. 21-82.

Žižek, Slavoj. 2013. Il trash sublime. Milano: Mimesis. 
